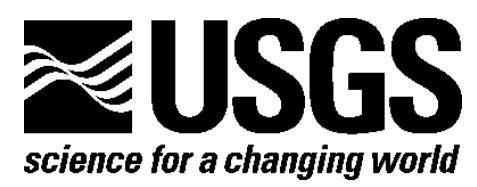

\title{
Migration Rates and Formation Injectivity to Determine Containment Time Scales of Sequestered Carbon Dioxide
}

By Lauri A. Burke

Open-File Report 2012-1062

U.S. Department of the Interior

U.S. Geological Survey 


\section{U.S. Department of the Interior \\ KEN SALAZAR, Secretary}

\section{U.S. Geological Survey \\ Marcia K. McNutt, Director}

U.S. Geological Survey, Reston, Virginia: 2012

For product and ordering information:

World Wide Web: http://www.usgs.gov/pubprod

Telephone: 1-888-ASK-USGS

For more information on the USGS-the Federal source for science about the Earth, its natural and living resources, natural hazards, and the environment:

World Wide Web: http://www.usgs.gov

Telephone: 1-888-ASK-USGS

Suggested citation:

Burke, L.A., 2012, Migration rates and formation injectivity to determine containment time scales of sequestered carbon dioxide: U.S. Geological Survey Open-File Report 2012-1062, 23 p.

Any use of trade, product, or firm names is for descriptive purposes only and does not imply endorsement by the U.S. Government.

Although this report is in the public domain, permission must be secured from the individual copyright owners to reproduce any copyrighted material contained within this report. 


\section{Contents}

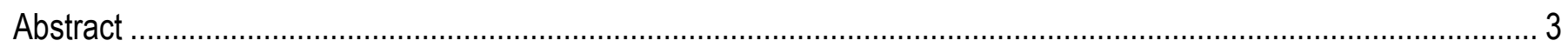

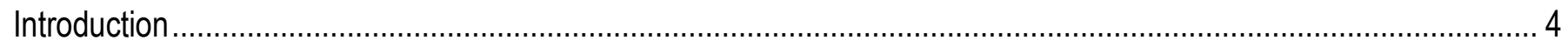

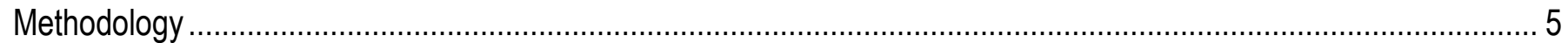

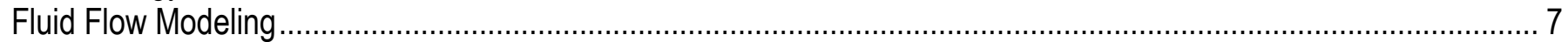

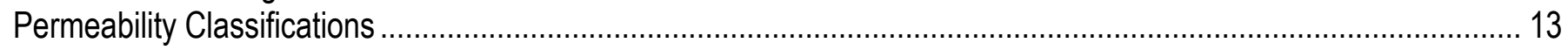

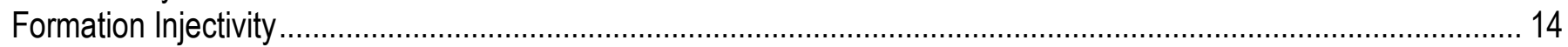

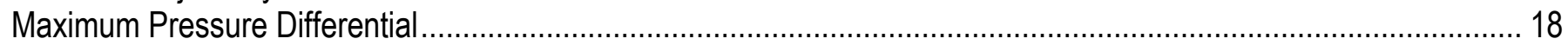

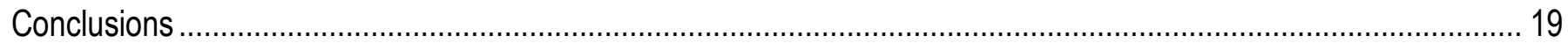

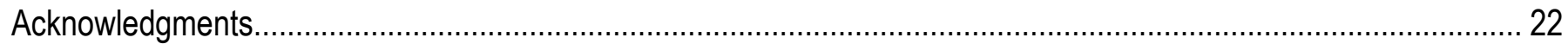

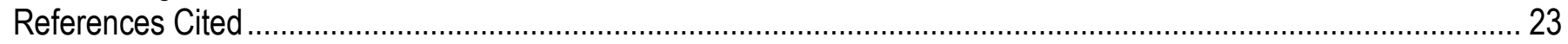




\section{Conversion Factors}

SI to Inch/Pound

\begin{tabular}{|c|c|c|}
\hline Multiply & By & To obtain \\
\hline \multicolumn{3}{|c|}{ Length } \\
\hline centimeter $(\mathrm{cm})$ & 0.3937 & inch (in.) \\
\hline meter $(\mathrm{m})$ & 3.281 & foot $(\mathrm{ft})$ \\
\hline kilometer $(\mathrm{km})$ & 0.6214 & mile (mi) \\
\hline \multicolumn{3}{|c|}{ Area } \\
\hline square centimeter $\left(\mathrm{cm}^{2}\right)$ & 0.1550 & square inch $\left(\right.$ in $\left.^{2}\right)$ \\
\hline \multicolumn{3}{|c|}{ Volume } \\
\hline cubic meter $\left(\mathrm{m}^{3}\right)$ & 6.290 & barrel (petroleum, 1 barrel = 42 gal) \\
\hline \multicolumn{3}{|c|}{ Mass } \\
\hline kilogram (kg) & 2.205 & pound avoirdupois (lb) \\
\hline \multicolumn{3}{|c|}{ Pressure } \\
\hline kilopascal $(\mathrm{kPa})$ & 0.1450 & pound per square inch $\left(\mathrm{lb} / \mathrm{in}^{2}\right)$ \\
\hline \multicolumn{3}{|c|}{ Density } \\
\hline kilogram per cubic meter $\left(\mathrm{kg} / \mathrm{m}^{3}\right)$ & 0.06242 & pound per cubic foot $\left(\mathrm{lb} / \mathrm{ft}^{3}\right)$ \\
\hline kilogram per cubic meter $\left(\mathrm{kg} / \mathrm{m}^{3}\right)$ & 0.008345 & pounds per gallon (ppg) \\
\hline kilogram per cubic meter $\left(\mathrm{kg} / \mathrm{m}^{3}\right)$ & 0.000434 & $\begin{array}{l}\text { pounds per square inch per foot } \\
\text { (psi/ft) }\end{array}$ \\
\hline \multicolumn{3}{|c|}{ Permeability } \\
\hline square meter $\left(\mathrm{m}^{2}\right)$ & $1.01325 \times 10^{12}$ & darcy (D) \\
\hline darcy (D) & $9.869233 \times 10^{-13}$ & square meter $\left(\mathrm{m}^{2}\right)$ \\
\hline
\end{tabular}

Temperature in degrees Celsius $\left({ }^{\circ} \mathrm{C}\right)$ may be converted to degrees Fahrenheit $\left({ }^{\circ} \mathrm{F}\right)$ as follows: ${ }^{\circ} \mathrm{F}=\left(1.8 \mathrm{x}^{\circ} \mathrm{C}\right)+32$.

Temperature in degrees Fahrenheit $\left({ }^{\circ} \mathrm{F}\right)$ may be converted to degrees Celsius $\left({ }^{\circ} \mathrm{C}\right)$ as follows:

${ }^{\circ} \mathrm{C}=\left({ }^{\circ} \mathrm{F}-32\right) / 1.8$. 


\section{Table of Symbols}

$\begin{array}{ll}A & \text { Cross-sectional area } \\ D & \text { Depth } \\ F_{\mathrm{D}} & \text { Fracture gradient at depth } \\ H_{\mathrm{D}} & \text { Hydrostatic gradient at depth } \\ K & \text { Bulk modulus } \\ k & \text { Matrix permeability } \\ L & \text { Lateral distance } \\ P & \text { Pressure } \\ Q & \text { Darcy fluid-flow rate } \\ v & \text { Interstitial pore velocity } \\ V_{\mathrm{p}} & \text { Velocity of compressional-waves in the formation } \\ \alpha & \text { Hydraulic diffusivity } \\ \beta & \text { Bulk compressibility of the formation } \\ \beta_{f} & \text { Fluid compressibility } \\ \Delta & \text { Gradient differential } \\ \Delta P & \text { Maximum pressure differential } \\ \eta & \text { Fluid viscosity } \\ \phi & \text { Fractional porosity } \\ \mu & \text { Shear modulus } \\ \rho & \text { Density } \\ \tau & \text { Time scale }\end{array}$




\title{
Migration Rates and Formation Injectivity to Determine Containment Time Scales of Sequestered Carbon Dioxide
}

\author{
Lauri Burke \\ U.S. Geological Survey
}




\section{Overview}

- Abstract and Introduction

- Methodology

- Fluid Flow Modeling

- Hydraulic Diffusivity

- Darcy's Law of Fluid Flow

- Permeability Classifications

- Formation Injectivity

- Maximum Pressure Differential

- Conclusions 


\section{Abstract}

Supercritical carbon dioxide exhibits highly variable behavior over a range of reservoir pressure and temperature conditions. Because geologic sequestration of supercritical carbon dioxide is targeted for subsurface injection and containment at depths ranging from approximately 3,000 to 13,000 feet, the investigation into the physical properties of this fluid can be restricted to the pressure and temperature conditions likely encountered in the sedimentary strata within this depth interval. A petrophysical based approach was developed to study the widest range of formation properties potentially encountered in sedimentary strata. Fractional porosities were varied from 5 to 95 percent, in 5 -percent increments, and permeability values were varied over thirteen orders of magnitude, from 10.0 darcys down to 1.0 picodarcy.

Fluid-flow modeling incorporated two constitutive equations from fluid dynamics: hydraulic diffusivity for near-surface applications, and Darcy's Law for deeper formations exhibiting higher pressure gradients. Based on the flow modeling results, first-order approximations of carbon dioxide lateral migration rates were determined. These first-order approximations enable the establishment of a permeability classification system for dividing the subsurface into flow units that provide short, moderate, and long-term containment of carbon dioxide. These results enable a probabilistic determination of how fluids will enter and be contained in a subsurface storage formation, which is a vital step in the calculation of the carbon dioxide storage capacity of a reservoir.

Additionally, this research establishes a methodology to calculate the injectivity of a target formation. Because injectivity describes the pressure increase due to the introduction of fluids into a formation, the relevant application of injectivity is to determine the pressure increase, due to an injection volume and flow rate, that will induce fractures in the reservoir rocks. This quantity is defined mathematically as the maximum pressure differential between the hydrostatic gradient and the fracture gradient of the target formation.

Injectivity is mathematically related to the maximum pressure differential of the formation, and can be used to determine the upper limit for the

pressure increase that an injection target can withstand before fracturing. 


\section{Introduction}

- This study quantifies first-order approximations for the time scales of carbon dioxide $\left(\mathrm{CO}_{2}\right)$ lateral migration through a 1.0kilometer $(\mathrm{km})$ representative volume of rock

- For characterization and classification of subsurface strata into subdivisions based on petrophysical criteria, and

- Incorporated into the U.S. Geological Survey assessment methodology for fully probabilistic determination of the storage capacity of geologic formations for $\mathrm{CO}_{2}$ sequestration (Brennan, et al., 2010; Burruss et al., 2009) 


\section{Thermophysical Properties of $\mathrm{CO}_{2}$}
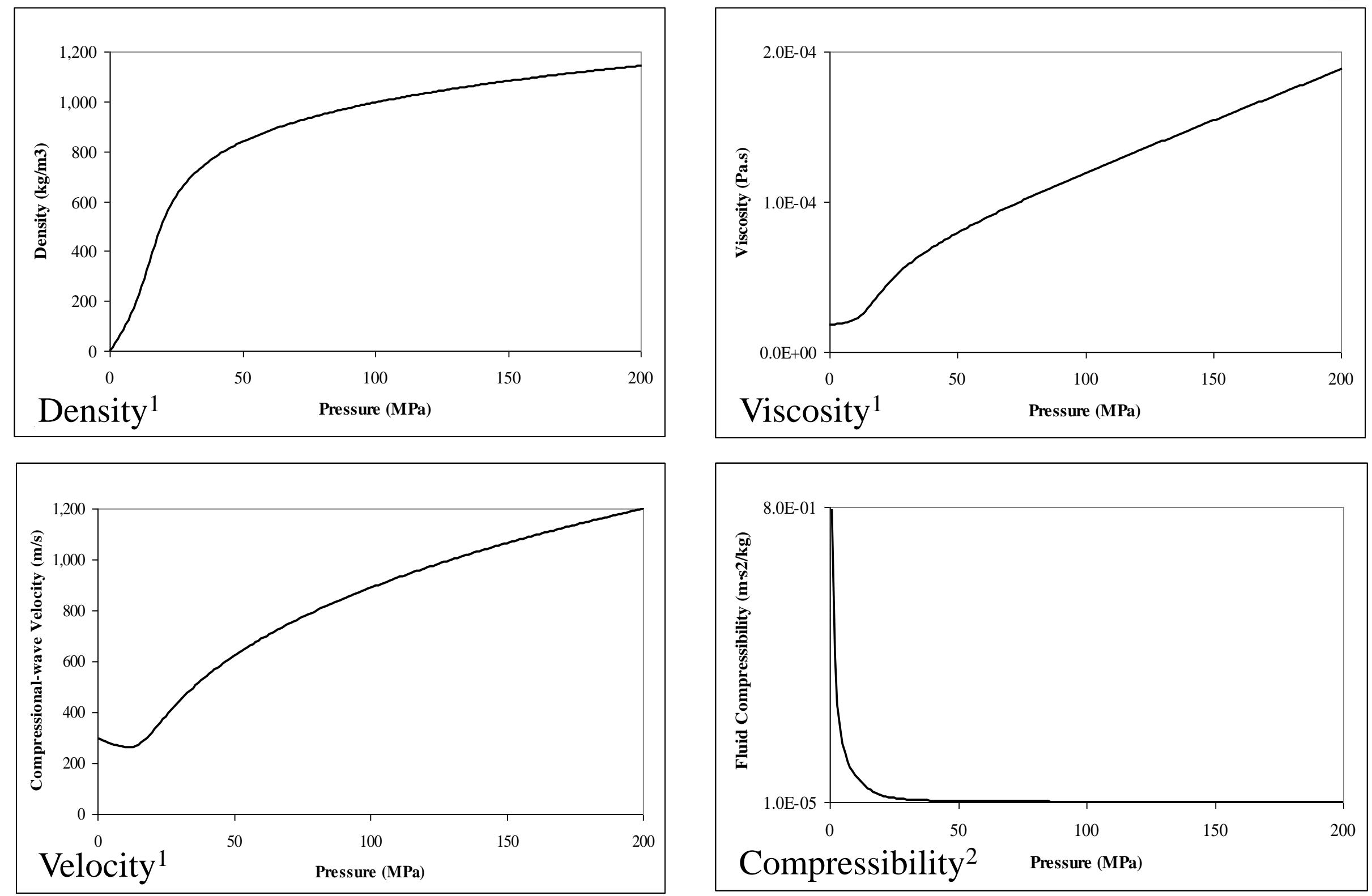

${ }^{1}$ Data from Lemmon and others, (2011) using Span and Wagner (1996) equations

${ }^{2}$ Calculated from $\mathrm{Vp}=[(4 / 3 \mu+\mathrm{K}) / \rho]^{1 / 2}$ 


\section{Approach}

- $\mathrm{CO}_{2}$ sequestration is targeted for injection and subsurface containment at depths from approximately 3,000 to $13,000 \mathrm{ft}$

- Midpoint is $8,000 \mathrm{ft}$

- Normally geopressured region with 100,000 parts per million total dissolved solids:

$0.465 \mathrm{psi} / \mathrm{ft}$ (Schlumberger, 2012)

- Generalized geothermal gradient for shallow crustal rocks:

$1.65^{\circ} \mathrm{F} / 100 \mathrm{ft}$ (Sheriff, 1994)

- Average surface temperature: $68^{\circ} \mathrm{F}$

- Pressure and temperature conditions of an "average" sedimentary formation at $8,000 \mathrm{ft}: 25.5 \mathrm{MPa}$ and $200{ }^{\circ} \mathrm{F}$ 


\section{Fluid Flow Modeling}

Hydraulic Diffusivity time scale, $\tau_{h d}$, in years:

$$
\tau_{h d}=\frac{L^{2}}{2 \alpha} \quad \text { where } \quad \alpha=\frac{k}{\eta\left(\frac{\phi \beta}{1-\phi}+\phi \beta_{f}\right)}
$$

Darcy's Law time scale, $\tau_{D}$, in years:

$$
\tau_{D}=\frac{\eta \phi L^{2}}{k \Delta P} \quad \text { from } \quad Q=\frac{k A}{\eta} \frac{\Delta P}{L} \quad \text { and } \quad v=\frac{k \Delta P}{\eta \phi L}
$$




\section{Flow Modeling Parameters}

\begin{tabular}{|c|c|c|c|c|}
\hline & Property & Variable & Value & Units \\
\hline \multirow{4}{*}{ 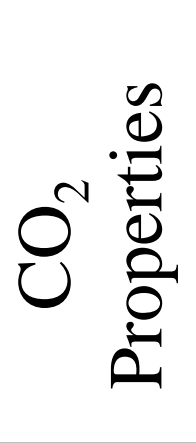 } & Viscosity & $\eta$ & $5.00 \mathrm{E}-05$ & $\mathrm{~kg} / \mathrm{m} \cdot \mathrm{s}$ \\
\hline & Fluid Density & $\rho$ & 628.06 & $\mathrm{~kg} / \mathrm{m}^{3}$ \\
\hline & Fluid Compressibility & $\beta_{f}$ & $1.66 \mathrm{E}-02$ & $\mathrm{MPa}^{-1}$ \\
\hline & $\begin{array}{l}\text { Compressional-wave } \\
\text { Velocity }\end{array}$ & $V_{p}$ & 390.28 & $\mathrm{~m} / \mathrm{s}$ \\
\hline \multirow{5}{*}{ 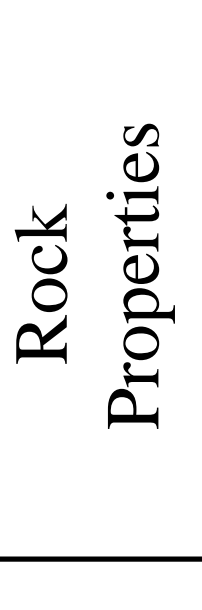 } & Bulk Compressibility & $\beta$ & $3.10 \mathrm{E}-02$ & $\mathrm{MPa}^{-1}$ \\
\hline & Lateral Distance & $L$ & 1.00 & $\mathrm{~km}$ \\
\hline & Fractional Porosity & $\phi$ & varies & dimensionless \\
\hline & Matrix Permeability & $k$ & varies & $\mathrm{D}$ \\
\hline & Darcy Pressure Differential & $\Delta P$ & 25.5 & $\mathrm{MPa}$ \\
\hline
\end{tabular}

Fluid Properties

-At 25.5 MPa and $200^{\circ} \mathrm{F}$

Rock Properties

-Fractional porosity varies from 0.05 to 0.95

-Matrix permeability varies from $1.00 \mathrm{E}+01$ to $1.00 \mathrm{E}-12 \mathrm{D}$ 


\section{Hydraulic Diffusivity Results}
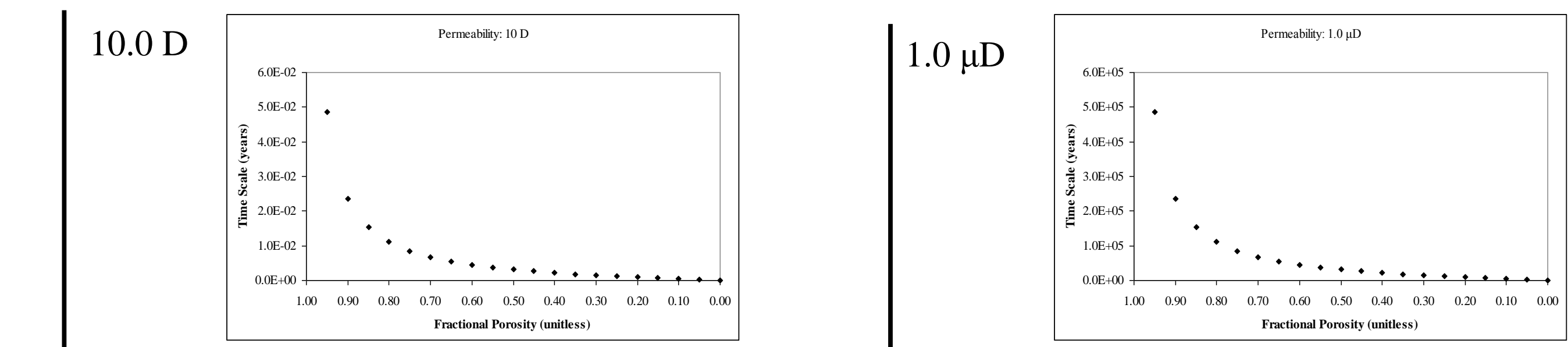

$1.0 \mathrm{D}$
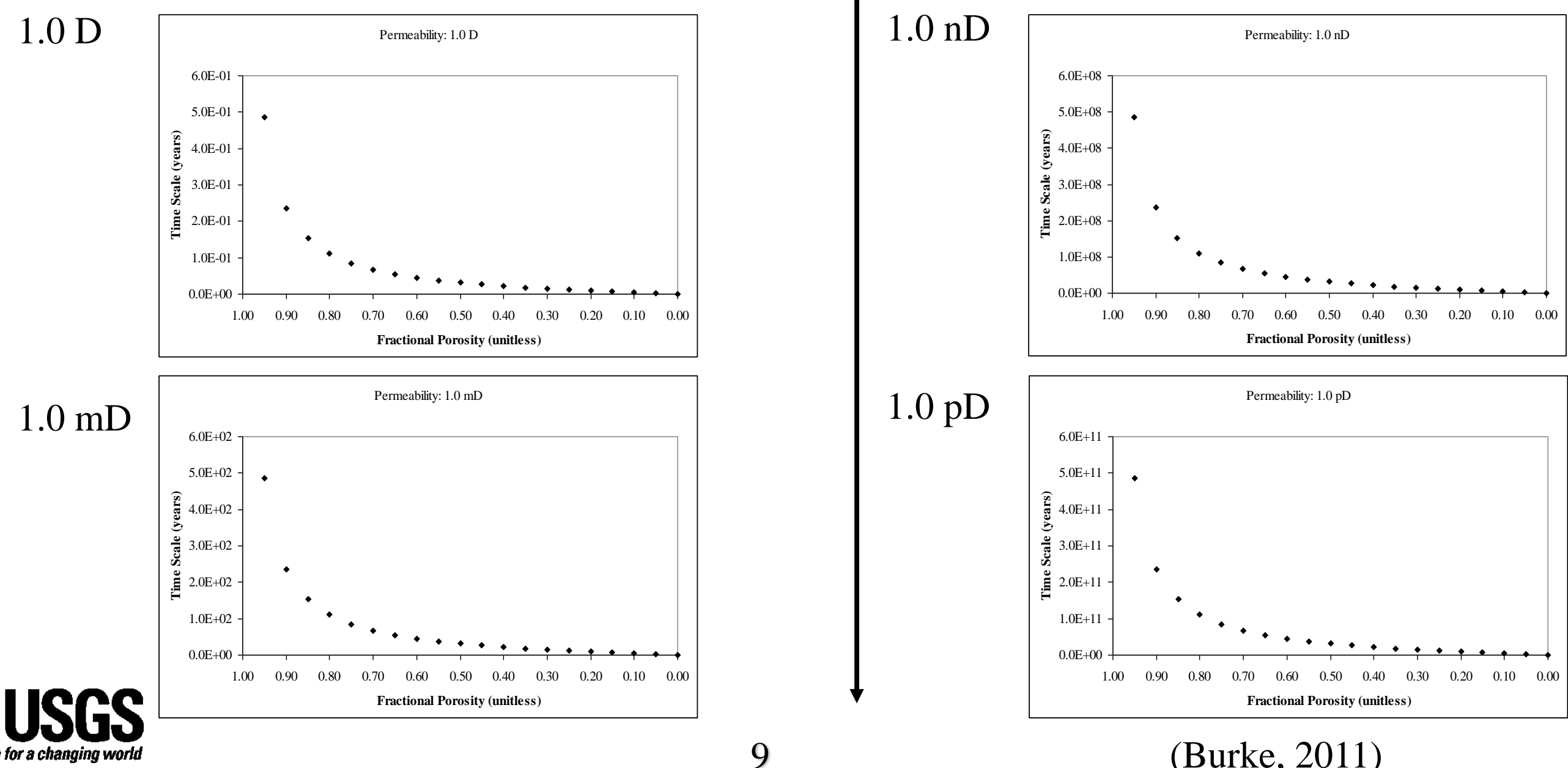

$1.0 \mathrm{pD}$

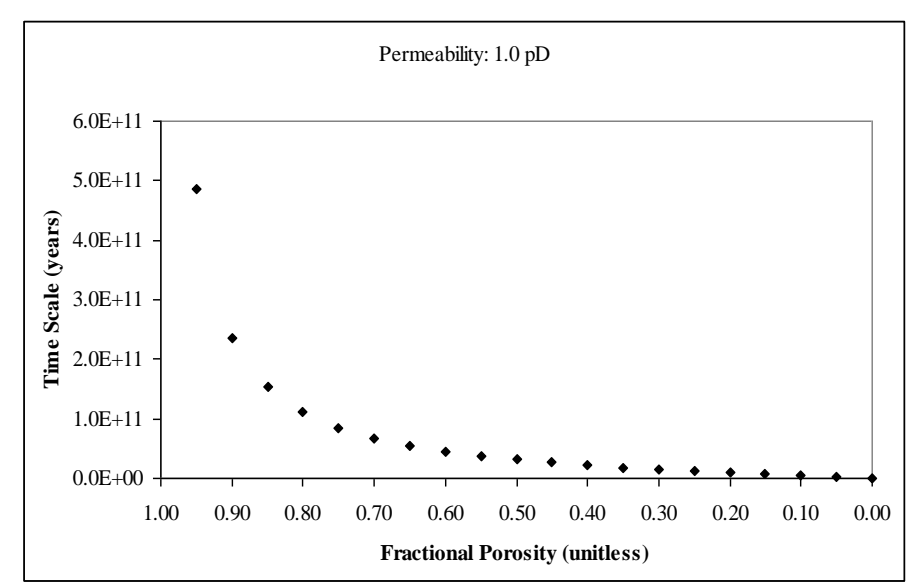

(Burke, 2011) 


\section{Hydraulic Diffusivity Results}

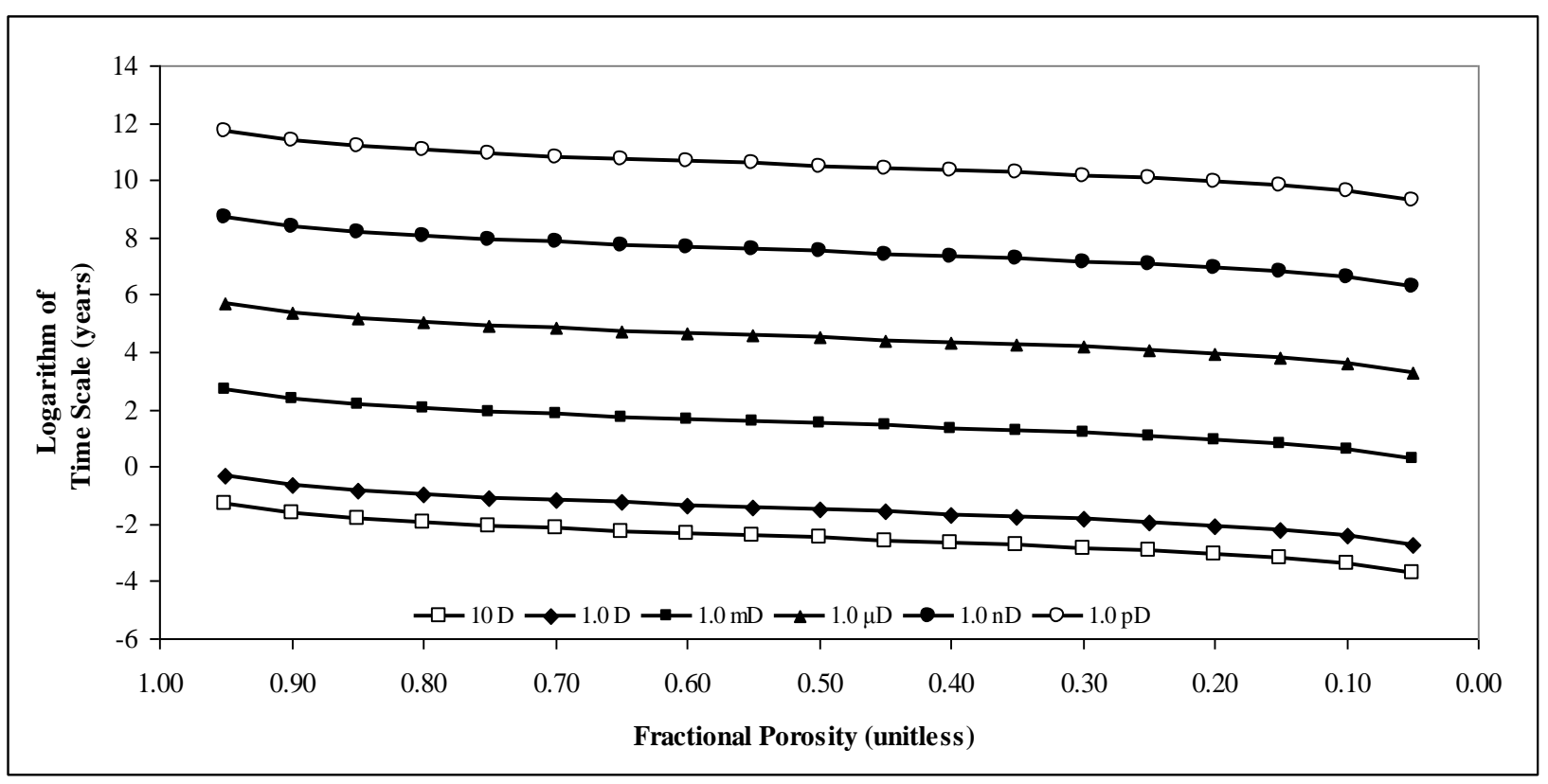

\begin{tabular}{|c|c|c|c|}
\hline $\begin{array}{c}\text { Permeability } \\
\text { (Darcy) }\end{array}$ & $\begin{array}{c}\text { Lower Bound } \\
\text { (Years) }\end{array}$ & $\begin{array}{c}\text { Average } \\
\text { (Years) }\end{array}$ & $\begin{array}{c}\text { Upper Bound } \\
\text { (Years) }\end{array}$ \\
\hline \multicolumn{5}{|c|}{} & $1.0 \mathrm{E}-3.70$ & $1.0 \mathrm{E}-2.50$ & $1.0 \mathrm{E}-1.63$ \\
\hline $10.0 \mathrm{D}$ & $1.0 \mathrm{E}-2.70$ & $1.0 \mathrm{E}-1.50$ & $1.0 \mathrm{E}-0.31$ \\
\hline $1.0 \mathrm{D}$ & $1.0 \mathrm{E}+0.30$ & $1.0 \mathrm{E}+1.50$ & $1.0 \mathrm{E}+2.68$ \\
\hline $1.0 \mathrm{mD}+5.68$ \\
\hline $1.0 \mu \mathrm{D}$ & $1.0 \mathrm{E}+3.30$ & $1.0 \mathrm{E}+4.50$ & $1.0 \mathrm{E}+8.68$ \\
\hline $1.0 \mathrm{nD}$ & $1.0 \mathrm{E}+6.30$ & $1.0 \mathrm{E}+7.50$ & $1.0 \mathrm{E}+11.68$ \\
\hline $1.0 \mathrm{pD}$ & $1.0 \mathrm{E}+9.30$ & $1.0 \mathrm{E}+10.50$ & \\
\hline
\end{tabular}

Several days to several weeks Up to six months

Several hundred years, 500 years

Several thousand years

Hundreds of millions of years Billions of years 


\section{Darcy's Law of Fluid Flow}
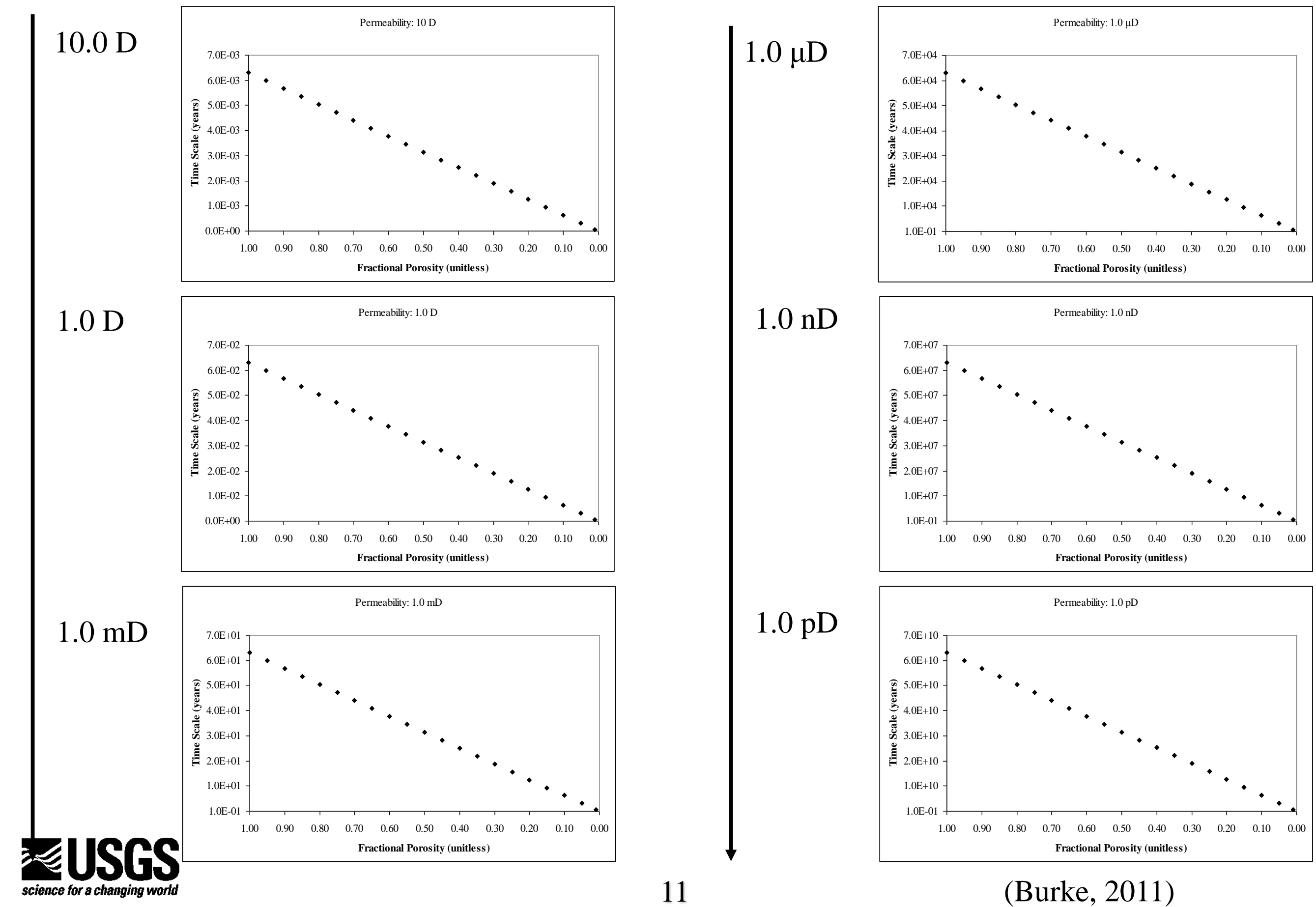

$1.0 \mathrm{pD}$

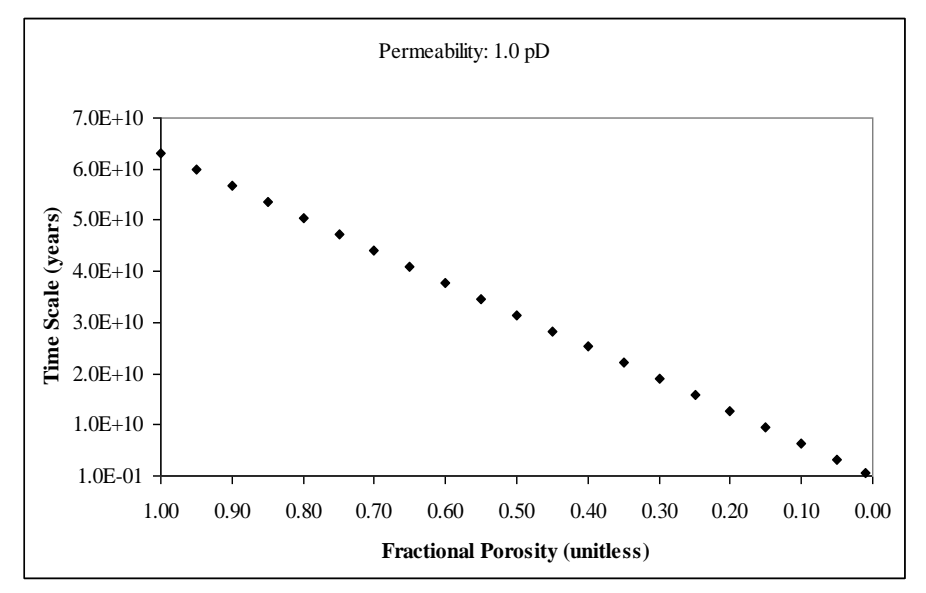

(Burke, 2011) 


\section{Darcy's Law of Fluid Flow}

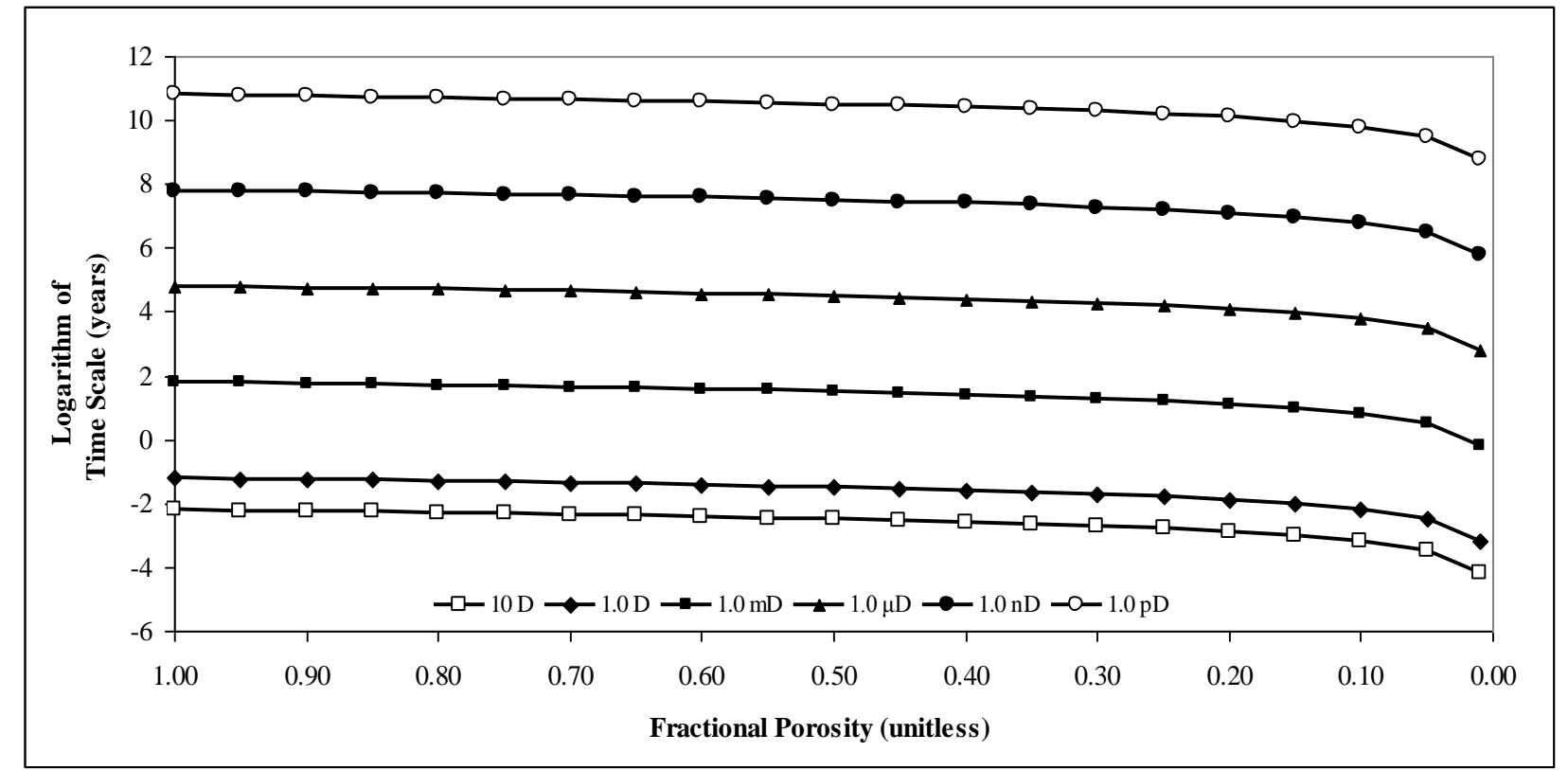

\begin{tabular}{|c|c|c|c|}
\hline $\begin{array}{c}\text { Permeability } \\
\text { (Darcy) }\end{array}$ & $\begin{array}{c}\text { Lower Bound } \\
\text { (Years) }\end{array}$ & $\begin{array}{c}\text { Average } \\
\text { (Years) }\end{array}$ & $\begin{array}{c}\text { Upper Bound } \\
\text { (Years) }\end{array}$ \\
\hline \multicolumn{5}{|c|}{} \\
\hline $10.0 \mathrm{D}$ & $1.0 \mathrm{E}-3.50$ & $1.0 \mathrm{E}-2.60$ & $1.0 \mathrm{E}-2.22$ \\
\hline $1.0 \mathrm{D}$ & $1.0 \mathrm{E}-2.50$ & $1.0 \mathrm{E}-1.60$ & $1.0 \mathrm{E}-1.22$ \\
\hline $1.0 \mathrm{mD}$ & $1.0 \mathrm{E}+0.50$ & $1.0 \mathrm{E}+1.40$ & $1.0 \mathrm{E}+1.77$ \\
\hline $1.0 \mu \mathrm{D}$ & $1.0 \mathrm{E}+3.50$ & $1.0 \mathrm{E}+4.40$ & $1.0 \mathrm{E}+4.77$ \\
\hline $1.0 \mathrm{nD}$ & $1.0 \mathrm{E}+6.50$ & $1.0 \mathrm{E}+7.40$ & $1.0 \mathrm{E}+7.77$ \\
\hline $1.0 \mathrm{pD}$ & $1.0 \mathrm{E}+9.50$ & $1.0 \mathrm{E}+10.40$ & $1.0 \mathrm{E}+10.77$ \\
\hline
\end{tabular}

Several days to weeks

Several months

6 months up to 60 years

Hundreds to several thousands of years

Tens of millions of years

Billions of years 


\section{Permeability Classifications}

\begin{tabular}{|c|l|}
\hline Classification & \multicolumn{1}{c|}{$\begin{array}{c}\text { Permeability Range } \\
\text { (Darcy) }\end{array}$} \\
\hline Class I & Class I $\geq 1.0 \mathrm{D}$ \\
\hline Class II & $1.0 \mathrm{D} \geq$ Class II $\geq 1.0 \mathrm{mD}$ \\
\hline Class III & Class III $\leq 1.0 \mathrm{mD}$ \\
\hline
\end{tabular}




\section{Formation Injectivity}

- The Oilfield Glossary (Schlumberger, 2012) defines an injectivity test as a procedure that is used to determine "the rate and pressure at which fluids can be pumped into the treatment target without fracturing the formation."

- According to Craft and Hawkins (1991) an injectivity index quantifies the pressure increase due to pumping a known rate and volume of fluids into the formation, and is the ratio of the injection flow rate divided by the pressure increase. 


\section{Formation Injectivity}

- Injectivity describes the pressure increase due to the introduction of fluids into a formation.

- The most interesting and relevant application of injectivity is to determine the pressure increase that will fracture the reservoir rocks. This is related to the fracture gradient. 


\section{Fracture Gradients}

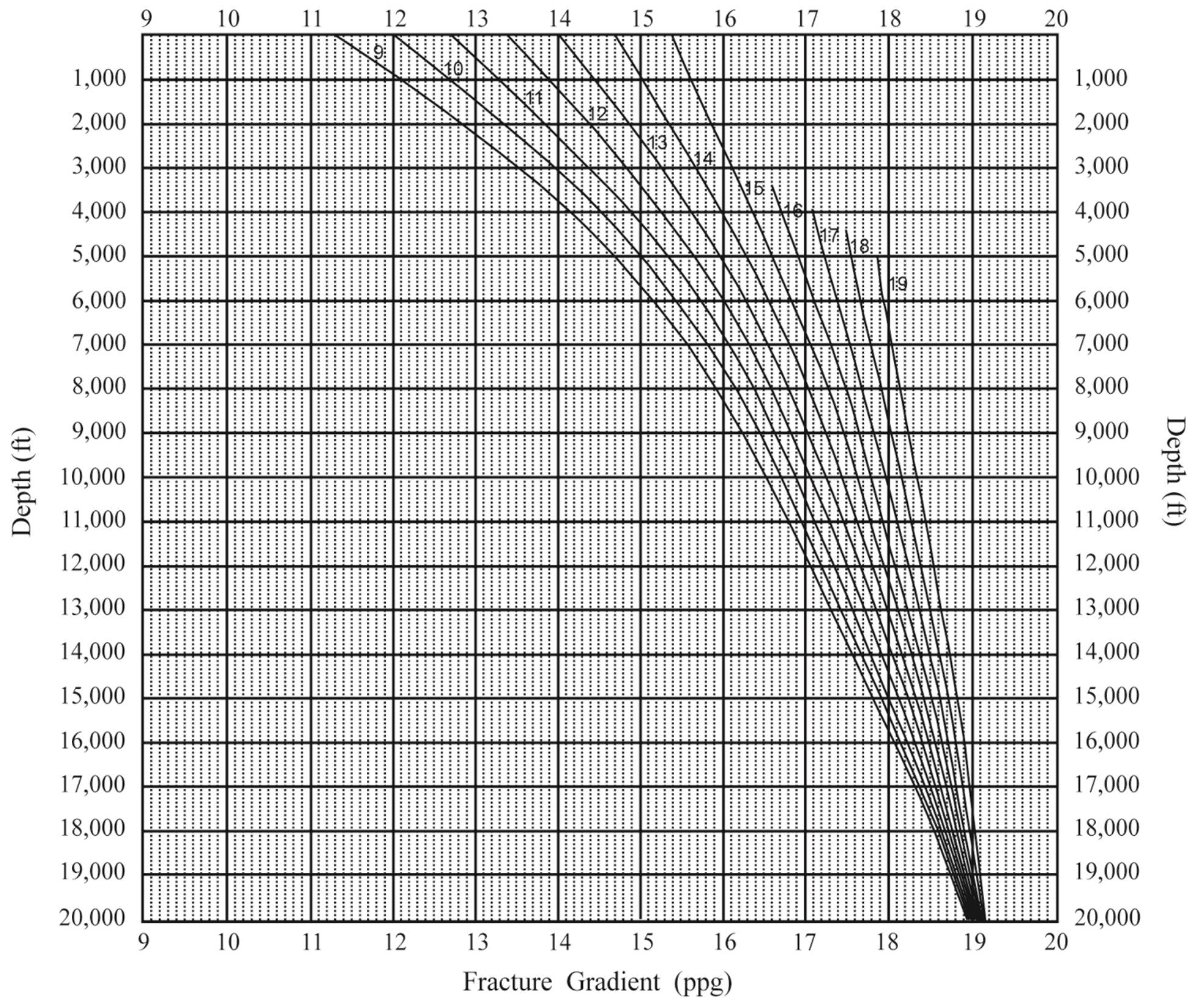




\section{Pressure Gradients}

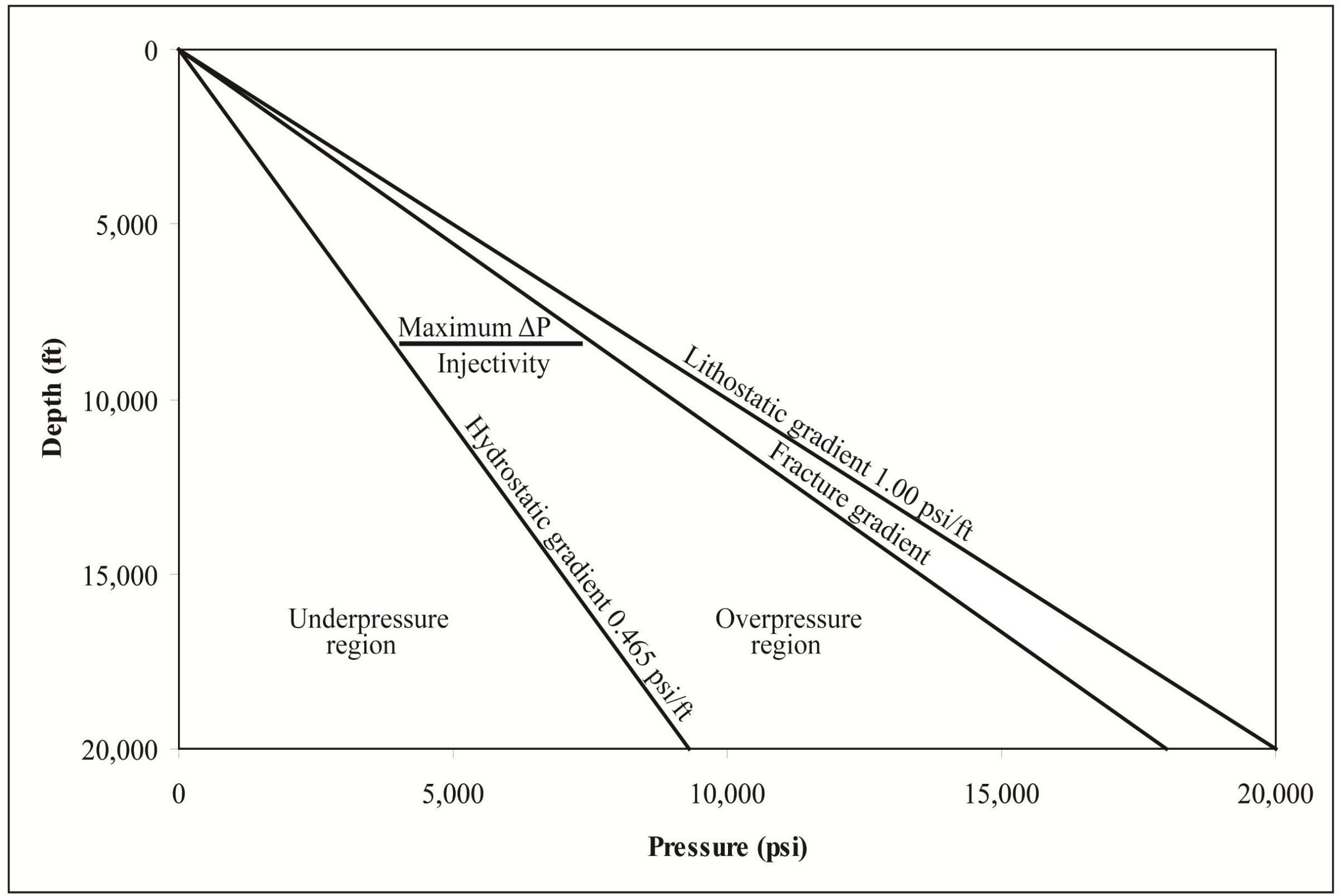




\section{Maximum Pressure Differential}

Maximum Pressure Differential, $\Delta P_{D}$, evaluated at a specific depth, $D$, is defined as:

$$
\Delta P_{D}=\left|F_{D}-H_{D}\right|
$$

$F_{D}$ fracture gradient as a function of depth, and

$H_{D}$ original reservoir pressure gradient or hydrostatic gradient as a function of depth

This relation assumes that the formation is not already fractured due to overpressuring, and that $\Delta P_{D}$ will always be a positive value, that is, increasing The pressure differential will not close the fractures. 


\section{Conclusions}

- Quantification of the first-order approximations of the time scales involved in the lateral migration of sequestered $\mathrm{CO}_{2}$ through a given volume of rock enables a general estimation of the containment timeframes of the sequestered gas. This study investigated these time scales for formations exhibiting permeabilities from 10.0 darcy to 1.0 picodarcy and porosities from 0.05 to 0.95 . 


\section{Conclusions (2)}

- Fluid flow modeling for determining fluid migration time scales

- Calculate generalized time scales of lateral $\mathrm{CO}_{2}$ fluid migration, given information about average reservoir temperature, pressure, permeability, and porosity.

- Hydraulic diffusivity time scales exhibit hyperbolic decay contours; Darcy fluid flow time scales exhibit decreasing linear trends.

- The orders of magnitude can be approximated as linear over a wide range of permeability-porosity values.

- Similar order of magnitude results for diffusivity and Darcy flow suggest that these first-order approximations, derived from two separate equations with different input values, yield a reliable estimation of the $\mathrm{CO}_{2}$ lateral migration time scales. 


\section{Conclusions (3)}

- Formations categorized by:

- Class I permeability may not provide adequate, long-term containment of sequestered $\mathrm{CO}_{2}$ in the absence of physical trapping mechanisms. Fluid migration occurs on the order of days to weeks.

- Class II permeability represents the most favorable scenario for injection and containment of $\mathrm{CO}_{2}$. The order of magnitude for $1.0-\mathrm{km}$ lateral migration of carbon dioxide through a given volume of rock ranges from several years to several thousand years.

- Class III permeability may not represent viable injection targets without formation treatments such as hydraulic fracturing or permeability enhancement. Lateral fluid migration occurs on the order of several hundreds to several hundred thousands of years. 


\section{Acknowledgments}

I thank several of my colleagues at the U.S. Geological Survey for their collaboration and support in this study, especially:

S. Brennan, R. Burruss, M. Buursink, R. Charpentier, T. Cook, R. Drake, R. Dubiel, P. Freeman, H. Jahediesfanjani, S. Kinney, M. Merrill, P. Nelson, L. Ruppert, and P. Warwick. 


\section{References Cited}

Brennan, S.T., Burruss, R.C., Merrill, M.D., Freeman, P.A., and Ruppert, L.F., 2010, A probabilistic assessment methodology for the evaluation of geologic carbon dioxide storage: U.S. Geological Survey Open-File Report 2010-1127, 31 p., accessed December 10, 2010, at http://pubs.usgs.gov/of/2010/1127.

Burke, L., 2011, Carbon dioxide fluid-flow modeling and injectivity calculations: U.S. Geological Survey Scientific Investigative Report 2011-5083, 16 p., accessed January 10, 2012 at http://pubs.usgs.gov/sir/2011/5083/sir2011-5083.pdf

Burruss, R.C., Brennan, S.T., Freeman, P.A., Merrill, M.D., Ruppert, L.F., Becker, M.F., Herkelrath, W.N., Kharaka, Y.K., Neuzil, C.E., Swanson, S.M., Cook, T.A., Klett, T.R., Nelson, P.H., and Schenk, C.J., 2009, Development of a probabilistic assessment methodology for evaluation of carbon dioxide storage: U.S. Geological Survey Open-File Report 2009-1035, 81 p., accessed January 11, 2011, at http://pubs.usgs.gov/of/2009/1035/.

Craft, B.C., and Hawkins, M.F, 1991, Applied petroleum reservoir engineering, 2nd ed., revised by R.E. Terry: Englewood Cliffs, N.J., Prentice Hall, 431 p.

Eaton, B.A., 1969, Fracture gradient prediction and its application in oilfield operations: Journal of Petroleum Technology, v. 21, no. 10, p. $1353-1360$.

Lemmon, E.W, McLinden, M.O., and Friend, D.G., 2011, Thermophysical properties of fluid systems in NIST chemistry webbook, NIST Standard Reference Database Number 69, in Linstrom, P.J., and Mallard, W.G., eds., National Institute of Standards and Technology: Gaithersburg, MD, accessed January 7, 2011, at http://webbook.nist.gov/chemistry/fluids.

Schlumberger, 2012, Schlumberger oilfield glossary: Normal pressure, accessed January 4, 2012, at http://www.glossary.oilfield.slb.com/Display.cfm?Term=normal\%20pressure.

Sheriff, R.E.,1994, Encyclopedia dictionary of exploration geophysics: Society of Exploration Geophysicists, Tulsa, OK, 1994.

Span, R., and Wagner, W., 1996, A new equation of state for carbon dioxide covering the fluid region from the triple-point temperature to $1100 \mathrm{~K}$ at pressures up to $800 \mathrm{MPa}$ : Journal of Physical and Chemical Reference Data, v. 25, no. 6, p. $1509-1597$. 